\title{
PEMIKIRAN PEMBAHARUAN FAZLUR RAHMAN \\ DALAM MENGATASI PROBLEMATIKA PENDIDIKAN ISLAM
}

\author{
ALFAUZAN AMIN
}

\begin{abstract}
This paper aims to reveal the problematic Islamic education perspective of Fazlur Rahman and the thinking of renewal of its renewal. The emergence of Rahman's ideas is motivated by his appreciation of the development of Islamic education in the modern era in some predominantly Muslim countries such as Turkey, Indonesia, Egypt and Pakistan. According to Fazlur Rahman Islamic education in these countries are still faced with problems; Educational goals are not directed toward positive goals. The dichotomy of the education system. The low quality of the students, the emergence of broken and unborn persons who have deep spiritual and intellectual commitment to Islam. Difficult to find qualified and professional educators and have a creative mind and integrated. Lack of books available in the library. To overcome this according to Rahman there are three efforts that must be done: (1) Orienting the goal of Islamic Education to the life of the world and akherat as well and sourced from the Qur'an. (2) Eliminating the psychological burden of Muslims in the face of the West. (3) Eliminating negative attitudes toward science. The existence of the dichotomy of the Islamic education system has led to the low quality of the students, the emergence of broken and unborn persons who have deep spiritual and intellectual commitment to Islam. To overcome this problem there are four attempts to be made: (1) Providing Qur'anic lessons and systematic commentary methods, enabling the Qur'an not only serve as a source of moral inspiration but also serve as a central reference for problem solving emerge to surface. (2) Provide material in the discipline of Islamic sciences historically, critically, and diverge, so that through this effort can integrate these thoughts into the concept of a complete and integrated Islam. (3) Intensify the mastery of foreign languages such as Arabic and English in addition to the national language. (4) Growing tolerant attitude to dissent.
\end{abstract}

Kata Kunci : Pemikiran, Pembaharuan, Fazlur rahman, Pendidikan Islam 


\section{A. PENDAHULUAN}

Penetrasi Barat terhadap dunia Islam ketika memasuki abad ke 18 M, mengalami desakan cukup hebat. Hal ini membuat umat Islam membuka mata dan menyadari betapa mundurnya umat Islam itu jika dihadapkan dengan kemajuan Barat. Untuk mengobati kemunduran umat Islam tersebut, maka pada abad ke-20 mulailah diadakan usaha-usaha pembaharuan dalam segala bidang kehidupan manusia termasuk dalam bidang pendidikan.

Manurut Fazlur Rahman; Meskipun telah dilakukan usaha-usaha pembaharuan Pendidikan Islam, namun dunia pendidikan Islam masih saja dihadapkan pada beberapa problema. Tujuan pendidikan Islam yang ada sekarang ini tidaklah benar-benar diarahkan pada tujuan yang positif. Tujuan pendidikan Islam hanya diorientasikan kepada kehidupan akherat semata dan cenderung bersifat defensif, yaitu untuk menyelamatkan umat Islam dan pencemaran dan pengrusakan yang ditimbulkan oleh dampak gagasan Barat yang datang melalui berbagai disiplin ilmu, terutama gagasan-gagasan yang mengancam standar-standar moralitas tradisional Islam. ${ }^{1}$

Pada dasarnya ada tiga pendekatan pembaharuan pendidikan yang dilakukan pada waktu itu, yaitu pengislaman pendidikan sekuler modern, menyederhanakan silabus-silabus tradisional dan menggabungkan cabang-cabang ilmu pengetahuan lama dengan cabang-cabang ilmu pengetahuan modern.

Pertama, mengislamkan pendidikan sekuler modern. Pendekatan ini dilakukan dengan cara menerima pendidikan sekuler modern yang telah berkembang pada umumnya di Barat dan mencoba untuk “mengislamkan"nya, yaitu mengisinya dengan konsep-konsep kunci tertentu dari Islam. Ada dua tujuan dari mengislamkan pendidikan sekuler modern ini, yaitu; Membentuk watak pelajar-pelajar atau 
mahasiswa-mahasiswa dengan nilai-nilai Islam dalam kehidupan individu dan masyarakat, Memungkinkan para ahli yang berpendidikan modern menangani bidang kajian masing-masing dengan nilai-nilai Islam pada perangkat-perangkat yang lebih tinggi, menggunakan perspektif Islam untuk mengubah kandungan maupun orientasi kajian-kajian mereka. ${ }^{2}$

Kedua tujuan tersebut berkaitan erat antara yang satu dengan yang lainnya. Sehingga apabila pembentukan watak dengan nilai-nilai Islam yang dilakukan pada pendidikan tingkat pertama ketika pelajar-pelajar masih dalam usia muda dan mudah menerima kesan, tanpa sesuatu pun yang dilakukan untuk mewarnai pendidikan tinggi dengan orientasi Islam, maka pandangan pelajar-pelajar yang telah mencapai tingkat yang tinggi dalam pendidikannya akan tersekulerkan dan bahkan kemungkinan besar mereka akan membuang orientasi Islam apapun yang pernah mereka miliki. Hal ini akan terjadi dalam skala yang luas. ${ }^{3}$

Kedua, menyederhanakan silabus-silabus tradisional. Pendekatan ini diarahkan dalam kerangka pendidikan tradisional itu sendiri. Pembaharuan ini cenderung menyederhanakan silabus pendidikan tradisional yang sarat dengan materi-materi tambahan yang tidak perlu seperti: teologi zaman pertengahan cabang-cabang filsafat tertentu, seperti logika dan segudang karya tentang hukum Islam penyederhanaan ini berupa pengesampingan sebagian besar karya-karya dalam berbagai disiplin zaman pertengahan dan menekankan pada bidang hadits, bahasa dan kesusastraan Arab serta prinsip-prinsip tafsir Al-Qur'an. ${ }^{4}$

Ketiga, menggabungkan cabang-cabang ilmu pengetahuan baru. Dalam kasus seperti ini, lama waktu belajar diperpanjang dan disesuaikan dengan panjang lingkup kurikulum sekolah-sekolah dan akademi modern. Di Indonesia pada tingkat akademi telah dimulai dilakukan upaya-upaya yang ditujukan untuk menggabungkan ilmu-ilmu pengetahuan modern dengan ilmu-ilmu pengetahuan tradisional. 
Akan tetapi menurut Fazlur Rahman, integrasi dan penggabungan yang seperti diuraikan di atas tidak ada, karena sifat pengajaran yang umumnya mekanis dan hanya menyandingkan ilmu pengetahuan yang lama dengan ilmu pengetahuan yang modern. Situasi ini diperburuk lagi dengan masih minimnya jumlah buku-buku yang tersedia di perpustakaan. Sehingga hal ini mengakibatkan, di satu pihak pengajaran akan tetap mandul sekalipun anak didik mempunyai bakat dan kemauan, di lain pihak guru-guru yang berkualitas dan professional serta memiliki pikiran-pikiran yang kreatif dan terpadu tidak akan dihasilkan dalam skala yang mencukupi. Melihat kondisi yang demikian ini, Rahman mencoba menawarkan solusinya.

Oleh karena itu, untuk mengetahui bagaimana pemecahan problema pendidikan Islam tersebut, maka studi gagasan Fazlur Rahman tentang solusi problema pendidikan Islam modern menjadi sangat penting. Pembahasan secara berurut masalah pokok dalam makalah ini adalah: (1) Bagaimana Biografi Tokoh pembaharu pemikiran Islam (Fazlur Rahman), (2) Bagaimana latar belakang munculnya gagasan pendidikan Islam Fazlur Rahman?, (3) Bagaimana gagasan Fazlur Rahman tentang solusi atas berbagai problematika pendidikan Islam modern?

\section{B. PEMIKIRAN PEMBAHARUAN PENDIDIKAN ISLAM \\ 1. TUJUAN PENDIDIKAN}

Dewasa ini pendidikan Islam sedang dihadapkan dengan tantangan yang jauh lebih berat dari masa permulaan penyebaran Islam. Tantangan tersebut berupa timbulnya aspirasi dan idealisme umat manusia yang serba multi interest dan berdimensi nilai ganda dengan tuntutan hidup yang multi komplek pula. Ditambah lagi dengan beban psikologis umat Islam dalam menghadapi Barat bekas saingan jika bukannya musuh sepanjang sejarah. Kesulitan ini semakin menjadi akut karena faktor 
psikologis yang lain, yang timbul sebagai komplek pihak yang kalah, berbeda dengan kedudakan umat Islam klasik pada waktu itu umat Islam adalah pihak yang menang dan berkuasa.

Fenomena tersebut, menurut Syed Sajjad Husain dan Syed Ali Ashraf, telah menyuburkan tumbuhnya golongan-golongan penekan. Golongan-golongan ini dengan cepat meraih kekuasaan dari orang -orang yang pikiranya lebih cenderung kepada agama. Akibatnya munculah suatu ketergantungan dan pertentangan antara golongan sekular dengan golongan agama. Pertentangan ini telah menampakan diri secara terangterangan dibeberapa negara seperti Turki, Mesir, Pakistan dan Indonesia. ${ }^{5}$

Fenomena pada gilirannya mengakibatkan pendidikan Islam tidak diarahkan kepada tujuan yang positip. Tujuan pendidikan Islam cenderung berorientasi kepada kehidupan akhirat semata dan bersifat deventif. Hal ini sebagaimana yang dikemukakan oleh Rahman bahwa:

Strategi pendidikan islam yang ada sekarang ini tidaklah benar-benar diarahkan kepada tujuan yang positif, tetapi lebih cenderung bersifat defensif yaitu untuk menyelamatkan pikiran kaum Muslimin dari pencemaran atau kerusakan yang ditimbulkan oleh dampak gagasangagasan Barat yang datang melalui berbagai disiplin ilmu, terutama gagasan-gagasan yang akan meledakkan standar moralitas Islam. ${ }^{6}$

Dalam kondisi kepanikan spiritual itu, strategi pendidikan Islam yang dikembangkan diseluruh dunia Islam secara universal bersifat mekanis. Akibatnya munculah golongan yang menolak segala apa yang berbau Barat, bahkan ada pula yang mengharamkan pengambil alihan ilmu dan teknologinya. Sehingga apabila kondisi ini terus berlanjut akan dapat menyebabkan kemunduran umat Islam. Menurut Rahman, ada beberapa hal yang harus dilakukan.

Pertama, tujuan pendidikan Islam yang bersifat defensif dan cenderung berorientasi hanya kepada kehidupan akhirat tersebut harus 
segera diubah. Tujuan pendidikan Islam harus berorientasi kepada kehidupan dunia dan akhirat sekaligus serta bersumber pada Al-Qur'an. Menurutnya bahwa:

Tujuan pendidikan dalam pandangan Al-Qur'an adalah untuk mengembangkan kemampuan inti manusia dengan cara yang sedemikian rupa sehingga ilmu pengetahuan yang diperolehnya akan menyatu dengan kepribadian kreatifnya. ${ }^{7}$

Kedua, beban psikologis umat Islam dalam menghadapi Barat harus segera dihilangkan. Untuk menghilangkan beban psikologis umat Islam tersebut, Rahman menganjurkan supaya dilakukan kajian Islam yang menyeluruh secara historis dan sistematis mengenai perkembangan disiplin-disiplin ilmu Islam seperti teologi, hukum, etika, hadis ilmu-ilmu sosial dan filsafat, dengan berpegang kepada Al-Qur'an sebagai penilai. Sebab disiplin ilmu-ilmu Islam yang telah berkembang dalam sejarah itulah yang memberikan hasil kepada wujud intelektual dan spiritual masyarakat Muslim. Sehingga melalui upaya ini diharapkan dapat menghilangkan beban psikologis umat Islam dalam menghadapi Barat.

Ketiga, sikap negatif umat Islam terhadap ilmu pengetahuan juga harus diubah. Sebab menurut Rahman, ilmu pengetahuan tidak ada yang salah, yang salah adalah penggunanya. Ilmu tentang atom misalnya, telah ditemukan saintis Barat, namun sebelum mereka memanfaatkan tenaga listrik dari penemuan itu (yang dimaksud memanfaatkan energi hasil reaksi inti yang dapat ditransformasikan menjadi energi listrik) atau menggunakannya buat hal-hal yang berbguna, mereka menciptakan bom atom. Kini pembuatan bom atom masih terus dilakukan bahkan dijadikan sebagai ajang perlombaan. Para saintis kemudian dengan cemas mencari jalan untuk menghentikan pembuatan senjata dahsyat itu. 
Rahman juga menyatakan bahwa di dalam Al-Qur'an kata al-ilm (ilmu pengetahuan) digunakan untuk semua jenis ilmu pengetahuan. Contohnya, ketika Allah mengajarkan bagaimana Daud membuat baju perang, itu juga al-'ilm. Bahkan sihir (sihr), sebagaimana yang pernah diajarkan oleh Harut dan Marut kepada manusia, itu juga merupakan salah satu jenis al-'ilm meskipun jelek dalam arti praktek dan pemakaiannya. Sebab banyak yang menyalahgunakan sihir itu untuk memisahkan suami dari istrinya. Begitu pula hal-hal yang memberi wawasan baru pada akal termasul al-'ilm. ${ }^{8}$

\section{SISTEM PENDIDIKAN}

Persoalan dualisme dikotomi sistem pendidikan itu telah melanda seluruh negara Muslim atau negara yang mayoritas penduduknya beragama Islam. Bahkan menurut Syed Sajjad Husain dan Syed Ali Ashraf, dikotomi sistem pendidikan itu bukan hanya menyangkut perbedaan dalam struktur luarnya saja tapi juga perbedaan yang lahir dari pendekatan mereka terhadap tujuan-tujuan pendidikan.

Sistem tradisional kuno dalam Islam didasarkan atas seperangkat nilai-nilai yang berasal dari Al-Qur'an. Di dalam Al-Qur'an dinyatakan bahwa tujuan-tujuan pendidikan yang sesungguhnya adalah menciptakan manusia yang taat kepada Tuhan dan akan selalu berusaha untuk patuh pada perintah-perintah-Nya sebagaimana yang dituliskan dalam kitab suci. Orang semacam ini akan berusaha untuk memahami seluruh fenomena di dalam dan di luar khazanah kekuasaan Tuhan. Di lain pihak sistem modern, yang tidak secara khusus mengesampingkan Tuhan, berusaha untuk tidak melibatkan-Nya dalam penjelasannya mengenai asal-usul alam raya atau fenomena dengan mana manusia selalu berhubungan setiap harinya. 
Di tengah maraknya persoalan dikotomi sistem pendidikan Islam tersebut, Rahman berupaya untuk menawarkan solusinya. Menurutnya untuk menghilangkan dikotomi sistem pendidikan Islam tersebut adalah dengan cara mengintegrasikan antara ilmu-ilmu agama dengan ilmu-ilmu umum secara organis dan menyeluruh. Sebab pada dasarnya ilmu pengetahuan itu terintegrasi dan tidak dapat dipisahkan. ${ }^{9}$

Dengan demikian di dalam kurikulum maupun silabus pendidikan Islam harus tercakup baik ilmu-ilmu umum seperti ilmu sosial, ilmu-ilmu alam dan sejarah dunia maupun ilmu-ilmu agama seperti fiqih, kalam, tafsir, Hadis. Agaknya, metode integrasi seperti yang ditawarkan oleh Fazlur Rahman itulah yang pernah diterapkan pada masa keemasan Islam. Pada masa itu ilmu dipelajari secara utuh dan seimbang antara ilmu-ilmu yang diperlukan untuk mencapai kesejahteraan di dunia (ilmu-ilmu umum) maupun ilmu-ilmu untuk mencapai kebahagiaan di akhirat (ilmuilmu agama).

Pendekatan integralistik seperti itu, yang melihat adanya hubungan fungsional antara ilmu-ilmu umum dan ilmu-ilmu agama, telah berhasil melahirkan ulama-ulama yang memiliki pikiran-pikiran yang kreatif dan terpadu serta memiliki pengetahuan luas dan mendalam pada masa klasik. Ibn Sina misalnya, selain ahli agama, juga seorang psikolog, ahli dalam ilmu kedokteran dan sebagainya. Demikian pula dengan Ibn Rusyd, ia di samping sebagai ahli hukum Islam, juga ahli dalam bidang matematika, fisika, astronomi, logika, filsafat dan ilmu pengobatan. ${ }^{10}$ Adanya keseimbangan antara ilmu-ilmu umum (dunia) dengan ilmu-ilmu agama dalam suatu kurikulum pendidikan Islam, menurut Hasan Langgulung: ada gilirannya akan melahirkan spesialisasi pada bagian ilmu sesuai dengan periode perkembangan, sesuai dengan tingkat pendidikan, sesuai dengan spesilalisasi sempit pada tingkat pendidikan tinggi, di mesjid dan rumah hikmah/ Universitas kemudian hari sampai sekarang. ${ }^{11}$ 
Menurut Rahman bahwa ilmu pengetahuan itu pada prinsipnya adalah satu yaitu berasal dari Allah SWT. Hal ini sesuai degan apa yang dijelaskan di dalam Al-Qur'an. Menurut Al-Qur'an semua pengetahuan datangnya dari Allah. Sebagian diwahyukan kepada orang yang dipilihNya melalui ayat-ayat Qur'aniyah dan sebagian lagi melalui ayat-ayat kauniyah yang diperoleh manusia dengan menggunakan indra, akal dan hatinya. Pengetahuan yang diwahyukan mempunyai kebenaran yang absolut sedangkan pengetahuan yang diperoleh, kebenarannya tidak mutlak. ${ }^{12}$

Dari uraian di atas dapat dikatakan bahwa ilmu Allah dapat diketahui dan dipelajari melalui dua jalur yaitu jalur ayat-ayat Qur'aniyah dan jalur ayat-ayat kauniyah.

\section{PESERTA DIDIK}

Peserta Didik yang dihadapi oleh dunia pendidikan Islam di negara-negara Islam berkaitan erat dengan belum berhasilnya dikotomi antara ilmu-ilmu agama dengan ilmu-ilmu umum ditumbangkan di lembaga-lembaga pendidikan Islam. Belum berhasilnya penghapusan dikotomi antara ilmu-ilmu agama dengan ilmu-ilmu umum mengakibatkan rendahnya kualitas intelektual anak didik dan munculnya pribadi-pribadi yang pecah (split personality) dari kaum Muslim. Misalnya seorang muslim yang saleh dan taat menjalankan ibadah, pada waktu yang sama ia dapat menjadi pemeras, penindas, koruptor, atau melakukan perbuatan tercela lainnya. ${ }^{13}$ Bahkan yang lebih ironis lagi dikotomi sistem pendidikan tersebut mengakibatkan tidak lahirnya anak didik yang memiliki komitmen spiritual dan intelektual yang mendalam terhadap Islam dari lembaga-lembaga pendidikan Islam. Sebagian dari mereka lebih berperan sebagai pemain-pemain teknis dalam masalah-masalah agama. 
Sementara ruh agama itu sendiri jarang benar digumulinya secara intens dan akrab.

Menurut Rahman, beberapa usaha yang harus dilakukan untuk mengatasi masalah tersebut di atas. Pertama, anak didik harus diberikan pelajaran Al-Qur'an melalui metode-metode yang memungkinkan kitab suci bukan hanya dijadikan sebagai sumber inspirasi moral tapi juga dapat dijadikan sebagai rujukan tertinggi untuk memecahkan masalah-masalah dalam kehidupan sehari-hari yang semakin kompleks dan menantang. ${ }^{14}$ Dalam kaitan itu Rahman menawarkan metode sistematisnya dalam memahami dan menafsirkan Al Qur'an. Metode itu terdiri dari dua gerakan ganda yaitu dari situasi sekarang ke masa Al Qur'an diturunkan dan kembali lagi ke masa kini. Gerakan pertama mempunyai dua langkah.

a. Orang harus memahami arti atau makna dari suatu pernyataan dengan mengkaji situasi dan problem historis di mana pernyataan Al-Qur'an tersebut merupakan jawaban. Sebelum mengkaji ayat-ayat spesifiknya, suatu kajian mengenai situasi makro dalam batasan-batasan masyarakat, agama, adat-istiadat, lembaga-lembaga dan mengenai kehidupan secara menyeluruh di Arabia pada saat kehadiran Islam, khususnya di sekitar Mekkah harus dilakukan.

b. Menggenerasikan jawaban-jawaban spesifik tersebut dan menyatakannya sebagai pernyataan-pernyataan yang memiliki tujuan moral dan sosial umum yang dapat disaring dari ayat-ayat spesifik dalam sinaran latar belakang sosio-historis yang sering dinyatakan. Selama proses ini, perhatian harus diberikan kepada arah ajaran AlQur'an sebagai suatu keseluruhan sehingga setiap arti tertentu yang difahami, setiap hukum yang dinyatakan dan setiap tujuan yang dirumuskan akan koheren dengan yang lainnya. Al Qur'an sebagai suatu keseluruhan memang menanamkan sikap yang pasti terhadap hidup dan memenuhi suatu pandangan dunia yang kongkrit. ${ }^{15}$ 
Jika dua momen gerakan ganda ini dapat dicapai, menurut Rahman, perintah-perintah Al-Qur'an akan hidup dan efektif kembali. Metode penafsiran yang ditawarkan Rahman itulah yang disebutnya sebagai prosedur ijtihad. Dalam metode tersebut Rahman telah mengasimilasi dan mengkolaborasi secara sistematis pandangan yuridis Maliki dan Syathibi tentang betapa mendesaknya memahami Al-Qur'an sebagai suatu ajaran yang padu dan kohesif ke dalam gerakan pertama dari metodenya. Kedua, memberikan materi disiplin ilmu-ilmu Islam secara historis, kritis dan holistik. Disiplin ilmu-ilmu Islam itu meliputi: Teologi, hukum etika, ilmu-ilmu sosial dan filsafat.

\section{PENDIDIK (Mu’ALLIM)}

Untuk mendapatkan kualitas pendidik seperti itu di lembagalembaga pendidikan Islam dewasa ini sangat sulit sekali. Hal ini dibuktikan Rahman, melalui pengamatannya terhadap perkembangan pendidikan Islam di beberapa negara Islam. Ia melihat bahwa pendidik yang berkualitas dan profesional serta memiliki pikiran-pikiran yang kreatif dan terpadu yang mampu menafsirkan hal-hal yang lama dalam bahasa yang baru sejauh menyangkut substansi dan menjadikan hal-hal yang baru sebagai alat yang berguna untuk idealita masih sulit ditemukan pada masa modern. Masalah kelangkaan tenaga pendidik seperti ini telah melanda hampir semua negara Islam.

Dalam mengatasi kelangkaan tenaga pendidik seperti itu, Rahman menawarkan beberapa gagasan: merekrut dan mempersiapkan anak didik yang memiliki bakat-bakat terbaik dan mempunyai komitmen yang tinggi terhadap lapangan agama (Islam). Anak didik seperti ini harus dibina dan diberikan insentif yang memadai untuk membantu memenuhi keperluannya dalam peningkatan karir intelektual mereka. Apabila hal ini tidak segera dilakukan maka upaya untuk menciptakan pendidik yang 
berkualitas tidak akan terwujud. Sebab hampir sebagian besar pelajar yang memasuki lapangan pendidikan agama adalah mereka yang gagal memasuki karir-karir yang lebih basah. ${ }^{16}$

\section{Pemikirannya tentang Pendidikan Tinggi}

Esensi "Pendidikan Islam", menurut Rahman tidaklah memaksudkan perlengkapan dan peralatan-peralatan fisik atau kuasi-fisik pengajaran seperti buku-buku yang diajarkan ataupun struktur eksternal pendidikan, tetapi adalah apa yang menurut Rahman sebagai "intelektualisme Islam", karena bagi Rahman inilah esensi pendidikan tinggi Islam. Ia adalah pertumbuhan suatu pemikiran Islam yang asli dan memadai, yang harus memberikan kreteria untuk menilai keberhasilan atau kegagalan sebuah sistem pendidikan Islam. Perumusan pemikiran pendidikan tinggi Islam haruslah didasarkan kepada metoda penafsiran yang benar terhadap al-Qur'an. Mengapa masalah al-Qur'an harus ditempatkan sebagai titik pusat intelektualisme Islam. Jawabannya karena bagi Muslim al-Qur'an adalah kalam Allah yang diwahyukan secara harfiah kepada Nabi Muhammad, dan barangkali tidak ada dokumen keagamaan lain yang dipegang seperti itu ${ }^{17}$. Proses penafsiran yang diusulkan terdiri dari suatu gerakan ganda, dari situasi sekarang ke masa al-Qur'an diturunkan, dan kembali lagi ke masa kini. Karena al-Qur'an adalah respons ilahi, melalui ingatan dan pikiran Nabi, kepada situasi moral-sosial Arab pada masa Nabi.

Gerakan ganda yang dikemukakan "Rahman" terdiri dari dua langkah. Pertama, orang harus memahami arti atau makna dari sesuatu pernyataan dengan mengkaji situasi atau problem historis di mana pernyataan al-Qur'an tersebut merupakan jawabannya. "Kedua", menggeneralisasikan jawaban-jawaban spesifik tersebut dan menyatakannya sebagai pernyataan-pernyataan yang memiliki tujuan- 
tujuan moral sosial umum yang dapat disaring dari ayat-ayat spesifik dalam sinaran latar belakang sosio kultural dan rationes legis yang sering dinyatakan. Sedangkan Intelektualisme Islam yang dimaksud yaitu suatu sisi bertolak dari ajaran Islam yaitu Qur'an dan Hadits oriented, dan sisilain dapat dipertanggung jawabkan secara ilmu pengetahuan kontemporer.

Rahman, menawarkan perumusan pemikiran konsep pendidikan tinggi Islam haruslah didasarkan dan berangkat dari pemahaman yang benar dan pendalaman terhadap al-Qur'an, yang berfungsi sebagai petunjuk atau inspirasi bagi generasi muda Islam. Disertasi DR. 'Abdul Rahman Salih, tentang pendidikan berdasarkan al-Qur'an, karena "cara hidup Islami ditentukan dalam al-Qur'an; mengikuti ini, maka fondasifondasi teori pendidikan Islam pada dasarnya diambil dari al-Qur'an. Pendekatan apa pun yang mengabaikan fakta fundamental ini pasti akan menghasilkan persepsi-persepsi yang tidak akurat"18.

Rahman, terdapat kesadaran yang luas dan kadang-kadang mendalam akan adanya dikotomi dalam pendidikan, namum semua upaya ke arah integrasi yang asli sejauh ini, pada umumnya tidak membuahkan hasil. Rahman, mengatakan perlu mencermati ciri-ciri pokok upaya-upaya yang dilakukan untuk memperbahrui pendidikan Islam. Pada dasarnya ada dua segi orientasi pembaharuan. Salah satu pendekatannya menerima pendidikan sekuler modern sebagaimana telah berkembang secara umumnya di Barat dan mencoba untuk "mengislamkan"nya - yakni mengisi dengan konsep kunci tertentu dari Islam. Pendekatan ini memiliki dua tujuan: Pertama, membentuk watak pelajar-pelajar/mahasiswa-mahasiswa dengan nilai Islam dalam kehidupan dan masyarakat, dan kedua, untuk memungkinkan para ahli yang berpendidikan modern untuk menamai bidang kajian masingmasing dengan nilai-nilai Islam pada perangkat-perangkat yang lebih 
tinggi; menggunakan perspektif Islam, untuk mengubah - di mana perlu baik kandungan maupun orientasi kajian-kajian mereka.

Rahman, melihat ada dua arah upaya-upaya pembaharuan yang sedemikian jauh telah dilakukan. Dalam satu arah, pembaharuan ini telah terjadi hampir seluruhnya dalam kerangka pendidikan tradisional sendiri. Perubahan ini sebagian besar digerakkan oleh fenomena pembahruan pramodernis,.... pembaharuan ini telah cenderung "menyederhanakan" sillabus pendidikan tradisional, yang dilihatnya sarat dengan materimateri "tambahan yang tak perlu" seperti theologi zaman pertengahan, cabang-cabang filsafat tertentu (seperti logika). Pada arah kedua, suatu keragaman perkembangan telah terjadi, yang bisa diringkas dengan mengatakan bahwa ragam-ragam perkembangan tersebut semuanya mencerminkan upaya untuk menggabungkan dan memadukan cabangcabang pengetahuan modern dengan cabang-cabang pe-ngetahuan lama. Dalam kasus seperti ini, lama waktu belajar diperpanjang dan disesuaikan dengan panjang lingkup kurikulum. Rahman, melihat atau catatan percobaan di Indonesia, ditunjang dengan pelajaran-pelajaran sore hari yang diseleng-garakan menurut cara pendidikan rendah modern dari sekolah-sekolah masa kini dengan demikian memperpanjang jam belajar dan bukannya menambah jumlah tahun belajar. Sedangkan pada tingkat akademi, dalam percobaan di Indonesia, upaya-upaya ditujukan pada penggabungan ilmu-ilmu modern dengan ilmu-ilmu tradisional.

Banyak lembaga pendidikan tinggi Islam di Indonesia telah menekankan pelajaran bahasa Arab, dan banyak mahasiswa dan sarjana Indonesia bisa berbicara secara lancar dengan bahasa Arab klasik. Banyak lembaga pendidikan Islam Indonesia mengadakan hubungan dengan alAzhar melalui guru-guru besar tamu yang datang dari al-Azhar. Selain itu sejumlah mahasiswa Indonesia yang dikirim untuk belajar ke al-Azhar. Maka, dalam pandangan "Rahman", kemungkinan besar apabila diberikan 
waktu, kesempatan, dan kemudahan-kemudahan, Islam Indonesia pasti akan mampu mengembangkan suatu tradisi Islam pribumi yang bermakna, yang akan benar-benar bersifat Islam kreatif.

Percobaan-percobaan ini tak syak lagi adalah percobaan-percobaan yang di-laukan oleh al-Azhar Mesir dan sistem baru pendidikan Islam diperkenalkan di Turki sejak akhir tahun-tahun 1940-an. Rahman, menilai modernisasi al-Azhar, sebagai sampel lembaga pendidikan ilmu-ilmu keislaman, sekalipun telah diupayakan semenjak abad kesembilan belas, dapat dikatakan tak berubah dalam prosisi intelektual - spiritualnya. Menurutnya, efek pembaruan pada al-Azhar baru dirasakan dalam lapangan reorganisasi, sistem ujian, dan pengenalan pokok-pokok kajian baru, dan tidak dalam kandungan ilmu-ilmu Islam inti seperti teologi dan filsafat. ....Rahman menilai pernyataan yang dikemukakan oleh 'Abdul Muta'al al-Sha'idi yang menyatakan bahwa pendidikan yang diberikan di al-Azhar tidak bisa melahirkan mujtahid-mujtahid besar, yakni orangorang yang mempunyai kemampuan dan kehendak untuk melakukan pemikiran baru dalam berbagai aspek pemikiran Islam, sebagai sebuah "truisme".

Tampaknya, kurikulum pendidikan Islam tingkat tinggi yang dikehendaki oleh Rahman adalah kurikulum yang terbuka bagi kajiankajian filsafat dan sain-sain sosial. Rahman, sangat menekankan peranan filsafat sebagai kegiatan kritis analtis dalam melahirkan gagasan-gagasan yang bebas. Dalam hal ini filsafat berfungsi menyediakan alat-alat intelektual bagi teologi dalam menjalankan tugasnya "mem-bangun suatu pandangan dunia berdasarkan al-Qur'an". Rahman memandang penting keterlibatan sains-sains sosial. Sains-sains tersebut merupakan produk perkembangan modern yang berguna dalam memberikan keterangan kondisi obyektif suatu kehidupan dunia yang obyektif pengejawantahan ajaran-ajaran al-Qur'an. 
Upaya Rahman selanjutnya berkenaan dengan kelangkaan tenaga pendidik, mengangkat lulusan madrasah yang relatif cerdas atau menunjuk sarjana-sarjana modern yang telah memperoleh gelar doktor di universitas-universitas Barat dan telah berada di lembaga-lembaga keilmuan tinggi sebagai guru besar-guru besar bidang studi bahasa Arab, bahasa Persi, dan sejarah Islam. Upaya lain, para pendidik harus dilatih di pusat-pusat studi keislaman di luar negeri khususnya ke Barat. Hal ini pernah direalisasikan Rahman, sewaktu ia menjabat direktur Institut Pusat Penelitian Islam. Atas gagasan Rahman ini, Institut yang dipimpinnya berhasil menerbitkan jurnal berkala ilmiah yang berbobot yaitu Islamic Studies. Melalui jurnal inilah para anggota institut mulai menyumbangkan karya riset mereka yang bermutu, di samping beberapa buku dan suntingan-suntingan dari naskah-naskah klasik. Kasus institut ini melukiskan telah lahirnya kesarjanaan yang kreatif dan bertujuan.

Gagasan Rahman itu juga pernah diterapkan di Indonesia melalui pengiriman pendidik atau tenaga pengajar IAIN yang potensial untuk melanjutkan studinya ke universitas di negeri Barat yang mempunyai pusat-pusat studi Islam. Awal dari dampak positif pengiriman pengiriman pendidik ke luar negeri itu memang mulai terasa antara lain seperti terlaksananya pembaruan sistem, metode dan teknik di bidang pengajaran dan penyempurnaan struktur kelembagaan serta susunan kurikulum.

Upaya selanjutnya, mengangkat beberapa lulusan madrasah yang memiliki pengetahuan bahasa Inggris dan mencoba melatih mereka dalam teknik riset modern dan sebaliknya menarik para lulusan universitas bidang filsafat dan ilmu-ilmu sosial dan memberi mereka pelajaran bahasa Arab dan disiplin-disiplin Islam klasik seperti Hadis, dan yurisprudensi Islam. Di sini tampak Rahman ingin memberikan bekal ilmu pengetahuan secara terpadu baik kepada para lulusan madrasah maupun kepada mereka yang lulusan universitas. Sehingga melalui upayanya ini akan 
lahir pendidik-pendidik yang kreatif dan mempunyai komitmen yang kuat terhadap Islam.

Upayanya lagi, menggiatkan para pendidik untuk melahirkan karyakarya keislaman secara kreatif dan memiliki tujuan. Di samping menulis karya-karya tentang sejarah, filsafat, seni, juga harus mengkonsentrasikannya kembali kepada pemikiran Islam. Di samping itu para pendidik juga harus bersunggguh-sungguh dalam mengadakan penelitian dan berusaha untu menerbitkan karyanya tersebut. Bagi mereka yang memiliki karya yang bagus harus diberi penghargaan antara lain dengan meningkatkan gajinya.

\section{KESIMPULAN}

Kemunculan gagasan Rahman dilatarbelakangi oleh pengamatanya terhadap perkembangan pendidikan Islam di era modern di beberapa negara yang mayoritas penduduknya beragama Islam seperti Turki, Indonesia, Mesir dan Pakistan. Menurut Fazlur Rahman Pendidikan Islam di negara-negara tersebut masih dihadapkan kepada beberapa problema pendidikan yang antara lain berkaitan dengan; (1) Tujuan Pendidikan tidak diarahkan kepada tujuan yang positif. (2) Dikotomi sistem pendidikan. (3) Rendahnya kualitas anak didik, munculnya pribadipribadi yang pecah dan tidak lahirnya anak didik yang memiliki komitmen spiritual dan intelektual yang mendalam terhadap Islam. (4) Sulitnya menemukan pendidik yang berkualitas dan professional serta memiliki pikiran yang kreatif dan terpadu. (5) Minimnya buku-buku yang tersedia di perpustakaan.

Kontribusi terhadap upaya modernisasi pendidikan Islam meliputi lima bidang, yaitu: (1) Tujuan pendidikan. (2) Dikotomi sistem pendidikan. (3) Peserta Didik. (4) Pendidik (mu'alim). (5) Peralatan pendidikan. 
Beban psikologis umat Islam dalam menghadapi Barat telah menyebabkan tujuan pendidikan Islam tidak diarahkan kepada tujuan yang positif. Tujuan pendidikan Islam hanya berorientasi kepada kehidupan akherat semata dan bersifat defensif terhadap ilmu pengetahuan. Untuk mengatasi ini menurut Rahman ada tiga usaha yang harus dilakukan: (1) Mengorientasikan tujuan Pendidikan Islam kepada kehidupan dunia dan akherat sekaligus dan bersumber dari Al-Qur'an. (2) Menghilangkan beban psikologis umat Islam dalam menghadapi Barat. (3) Menghilangkan sikap negatif terhadap ilmu pengetahuan.

Adanya dikotomi sistem pendidikan Islam telah menyebabkan rendahnya kualitas anak didik, munculnya pribadi-pribadi yang pecah dan tidak lahirnya anak didik yang amemiliki komitmen spiritual dan intelektual yang mendalam terhadap Islam. Untuk mengatasi masalah ini ada empat usaha yang harus dilakukan: (1) Memberikan pelajaran AlQur'an dan metode tafsir sistematis, sehingga memungkinkan Al-Qur'an tidak saja berfungsi sebagai sumber inspirasi moral tetapi juga dijadikan sebagai rujukan sentral bagi pemecahan persoalan yang muncul ke permukaan. (2) Memberikan materi disiplin ilmu-ilmu Islam secara historis, kritis, dan menyelurruh, sehingga melalui upaya ini dapatmengintegrasikan pikiran-pikiran itu ke dalam konsep Islam yang utuh dan terpadu. (3) Mengintensifkan penguasaan bahasa asing seperti Bahasa Arab dan Bahasa Inggris disamping bahasa nasional. (4) Menumbuhkan sikap toleran terhadap perbedaan pendapat.

Penulis : Dr. Alfauzan Amin, M.Ag adalah dosen tetap pada Fakultas Tarbiyah dan Tadris dan dosen pada Program Pasca Sarjana (PPS)IAIN Bengkulu. Email : alfauzaniamini@yahoo.co.id 


\section{DAFTAR PUSTAKA}

Abd. A'la, "Islam sebagai Faith in Action; Menguak Liberalisme Teologi Fazlur Rahman", dalam Akademika Jurnal Studi Keislaman, Vol. XVI No. II (Surabaya: IAIN Sunan Ampel, 2005).

Adnan Taufiq, Islamisasi Pengetahuan, Bandung Pustaka. 1993.

Ali Fauzi Ihsan, Fazlur Rahman Sang Sarjana Sang Pemikir, Jakarta: LSAF, 1988.

Langgulung, Hasan, 1992, Asas-Asas Pendidikan Islam, Jakarta: Pustaka alHusna. 1992.

Madjid, Nurcholish, Islam Doktrin Dan Peradaban, Jakarta: Yayasan Wakaf Paramadina. 1992.

Ma'arif, Syafi'I, 1993, Peta Bumi Intelektualisme di Indonesia, Bandung: Mizan. 1993.

M. Arifin dan Zainuddin, Teori-teori Pndidikan Berdasarkan al-Qur'an, Jakarta: Rineka Cipta. 1990.

Pringgodigdo, Islam and Modernity; Transformation An Intellectual Tradition, Chicago: University of Chicago Press. 1977.

Rahman, Fazlur, Islam, New York: Anchor Book, 1984.

-------, Islam, Anchor Books, New York, 1968, dilengkapi edisi The Checago University, 1979,. Tej. Ahsin Mohammad, Pustaka, Bandung, cetakan III, 1997.

--------, Islam and Modernity, Transformation of an Intellectual Tradition, The University of Chicago, Chicagi, 1982., terj. Ahsin Mohammad, Pustaka, 1985. 
${ }^{1}$ Rahman, Fazlur, Islam, New York: Anchor Book, 1984, h. 86.

${ }^{2}$ Ibid., h. 131.

${ }^{3} I b i d .$, h. 131.

${ }^{4}$ Ibid., h. 138.

${ }^{5}$ Madjid, Nurcholish, Islam Doktrin Dan Peradaban, Jakarta: Yayasan Wakaf Paramadina. 1992. h. 399.

${ }^{6} I b i d .$, h. 422.

${ }^{7}$ Ibid.

${ }^{8}$ Adnan, Op.cit., h. 42.

${ }^{9}$ Ma'arif, Syafi'i, 1993, Peta Bumi Intelektualisme di Indonesia, Bandung: Mizan. 1993.

h. 68 .

${ }^{10} \mathrm{M}$. Arifin dan Zainuddin, Teori-teori Pendidikan Berdasarkan al-Qur'an, Jakarta: Rineka Cipta. 1990. h. 95.

${ }^{11}$ Langgulung, Hasan, 1992, Asas-Asas Pendidikan Islam, Jakarta: Pustaka al-Husna. 1992, h. 22.

${ }^{12}$ Adnan, Op.cit., h. 32.

${ }^{13}$ Ali Fauzi Ihsan, Fazlur Rahman Sang Sarjana Sang Pemikir, Jakarta: LSAF, 1988. h. 234.

${ }^{14}$ Adnan, Op.cit., h. 135

${ }^{15}$ Rahman, Fazlur, Islam, New York: Anchor Book, 1984 , h. 46.

${ }^{16}$ Adnan, Op.cit., h. 135.

${ }^{17}$ Rahman, Op.Cit. 1982, h. 1.

${ }^{18}$ Abdul Rahman Salih 'Abdullah, Eduucational Theory: a Qur'anic Qutlook., dalam A. Syafi'i Ma'arif, h. 8. 